\title{
Penggunaan Media Sosial Hubungannya dengan Pengetahuan Etika Komunikasi Islam dan Prestasi Belajar PAI
}

\author{
Aprilia Nurhida ${ }^{1}$, Arih Merdekasari ${ }^{2}$ \\ ${ }^{12}$ STIT Islamiyah Karya Pembangunan Paron, Ngawi \\ Email: Anhida18@gmail.com
}

\begin{abstract}
The study is a correlation study. Sampling uses purposive random sampling technique with the criteria of students aged 16-19 years. The number of sampel are 51 students in class X and XI SMA Muhammadiyah 1 Ngawi. Data collection instruments are; social media use scale, islamic communication ethics knowledge test and Raport of PAI. Data analysis through Bivariate Correlation shows that there is no correlation between social media use with the Islamic communication ethics knowledge and academic achievement in PAI. More deeply there are findings of correlation between Islamic communication ethics knowledge and aspects of social media use in social interaction and relaxation
\end{abstract}

Keywords: Social Media; Islamic Communication Ethichs, Academic Achievement; Adolescence

\section{Pendahuluan}

Ilmu teknologi dan komunikasi saat ini mengalami perkembangan yang sangat pesat. Kecanggihannya dapat diakses melalui smartphone atau alat komunikasi lainnya yang beredar di masyarakat luas. Harga yang terjangkau dan banyaknya varian yang bisa disesuaikan dengan kebutuhan dan daya beli, membuat alat komunikasi modern ini bisa dimiliki oleh banyak orang. kepemilikan telepon seluler di Indonesia saat ini adalah $85 \%$ dari total penduduk ${ }^{1}$.

Media sosial merupakan yang paling popular digunakan penduduk Indonesia melalui internet. KOMINFO mengungkapkan penggunaan media sosial menempati jumlah tertinggi, yaitu sebesar 95\% dari total 63 juta orang yang menggunakan internet di Indonesia. Twitter dan Facebook merupakan media sosial yang paling banyak digunakan di Indonesia ${ }^{2}$.

Media sosial sudah menjadi sarana komunikasi yang penting, begitu pula di kalangan remaja yang sedang menempuh pendidikan di SMA. Hasil survey terhadap 88 siswa di SMA Muhammadiyah 1 Ngawi, 27,59\% menyatakan sikap sering menggunakan media sosial, 24,14\% agak sering, $48.28 \%$ jarang serta $0 \%$ menyatakan tidak pernah menggunakan media sosial.

Dalam proses belajar, media sosial bisa digunakan sebagai salah satu media pembelajaran. Menurut Arsyad, pengembangan media pembelajaran dibagi menjadi 3, yaitu media berbasis audio, media berbasis audiovisual dan media berbasis komputer. ${ }^{3}$ Media internet merupakan bagian dari jenis pengembangan media pembelajaran yang

${ }^{1}$ KOMINFO, "Riset KOMINFO dan UNICEF Mengenai Perilaku Anak dan Remaja Menggunakan Internet," 18 Februari 2014, kominfo.go.id.

${ }^{2}$ KOMINFO, "Pengguna Internet i Indonesia 63 Juta orang," 7 November 2011, kominfo.go.od.

${ }^{3}$ Azhar Arsyad, Media Pembelajaran (Jakarta: PT Raja Grafindo Persada, 2011). 
telah memiliki berbagai macam fasilitas. Media social memberikan ruang untuk berinteraksi dalam menambah pengetahuan dan melakukan kegiatan yang berhubungan dengan tugas sekolah. Penggunaan media sosial sebagai media pembelajaran akan dapat membantu peningkatan hasil belajar.

Selain hal positif, terdapat pula hal negatif yang dilakukan remaja melalui media sosial. Remaja sering menunjukkan hal yang tidak sebenarnya di media sosial. Putri dkk memaparkan bahwa kalangan remaja sering memposting kegiatan sehari-hari mereka yang seakan menggambarkan gaya hidup yang mencoba mengikuti perkembangan jaman. Namun apa yang mereka posting tidak selalu menggambarkan keadaan gaya hidup mereka yang sebenarnya. ${ }^{4}$

Adanya perilaku remaja yang berbeda di media sosial menggambarkan sifat media sosial yang netral. Pada tahun 2014 KOMINFO bekerja sama dengan UNICEF melakukan sebuah penelitian mengenai penggunaan media digital oleh anak dan remaja. Analisa data memaparkan bahwa mayoritas komunikasi yang dilakukan menggunakan internet adalah dengan teman sebaya. Melalui internet anak dan remaja bisa belajar akan tetapi juga bisa terekspos hal-hal seperti pornografi ${ }^{5}$.

Menghadapi fakta tingginya penggunaan media sosial di Indonesia termasuk para siswa di sekolah, para pengelola pendidikan hendaknya lebih tanggap bersikap. Kurangnya pengelolaan pada hal ini akan menimbulkan masalah serius tidak hanya pada akademik siswa akan tetapi juga perilakunya dalam interaksi sosial.

Hal utama yang perlu dilakukan dalam mensikapi populernya penggunaan media sosial adalah memahami pemanfaatan penggunaan media sosial para siswa. Sesudah mengetahui hal ini akan lebih mudah untuk membuat studi lanjutan dan menemukan intervensi yang tepat apabila timbul permasalahan. Siswa

Penggunaan media sosial meliputi; (1) Social interaction, komunikasi dan berhubungan dengan orang lain. (2) Information seeking, mencari informasi guna mendidik diri sendiri. (3) Pass time, mengisi waktu luang sesudah bosan bekerja atau aktivitas tertentu. (4) Entertainment, memenuhi hiburan dan kesenangan. (5) Relaxation, menghilangkan stres dan agar dia bisa menjadi lebih tenang atau relax. (6) Communicatory utility, menggunakan fasilitas komunikasi di media sosial untuk berbagi informasi dengan orang lain. (7) Convenience utility, menggunakan fasilitas di media sosial yang berguna untuk dirinya sendiri'.

Remaja yang sudah dibekali dengan pendidikan agama yang kuat, mereka cenderung menggunakan media sosial sesuai dengan nilai agama. Namun bagi remaja yang kurang dibekali dengan pendidikan agama, mereka akan menggunakan media sosial tanpa memperhatikan nilai-nilai agama dan cenderung mengarah ke perbuatan yang

${ }^{4}$ Wilga Sersio Ratsja Putri, R. Nunung Nurwati, dan Budiarti S Meilanny, "Pengaruh Media Sosial Terhadap Perilaku Remaja," Prosiding KS ;Riset dan PKM 3, no. 1 (2017): 47-51.

${ }_{5}^{5}$ KOMINFO, "Riset KOMINFO dan UNICEF Mengenai Perilaku Anak dan Remaja Menggunakan Internet."

6 Anita Whiting dan David William, "Why people use social media: A uses and gratifications approach,” QMRIJ 16, no. 4 (Juni 2013), https:/ / doi.org/10.1108/QMR-06-2013-0041. 
negatif. Remaja yang menempuh pendidikan di sekolah islam dibekali pengetahuan agama salah satunya etika dalam berkomunikasi.

Etika komunikasi Islam di media sosial adalah norma atau aturan yang diterapkan dalam berkomunikasi atau berhubungan di media sosial yang sesuai dengan prinsipprinsip komunikasi Islam di media sosial. Hefni menjelaskan prinsip komunikasi islam mencakup; ikhlas, pahala dosa, kejujuran, kebersihan, berkata positif, konsistensi hati, lisan dan perbuatan. Pengawasan, privacy, keseimbangan berita, lebih banyak mendengar daripada berbicara, selektf dan memilih informasiyang valid ${ }^{7}$.

Penelitian Istriyana dan Widiana (2016) mengenai Etika komunikasi dalam membendung informasi hoax di ranah publik maya menjelaskan pentingnya penerapan etika komunikas yang akan membuat seseorang selektif dalam menentukan perilakunya etika menggunakan media sosial ${ }^{8}$. Berdasarkan uraian di atas, peneliti tertarik untuk melakukan penelitian tentang Penggunaan Media Sosial hubungannya dengan Pengetahuan Etika Komunikasi Islam dan prestasi belajar PAI.

Hipotesis sementara yang diajukan adalah: (1) Ada hubungan penggunaan media sosial terhadap pengetahuan etika komunikasi Islam pada siswa SMA Muhammadiyah1 Ngawi (2) Ada hubungan penggunaan media sosial terhadap prestasi belajar PAI pada siswa SMA Muhammadiyah 1 Ngawi.

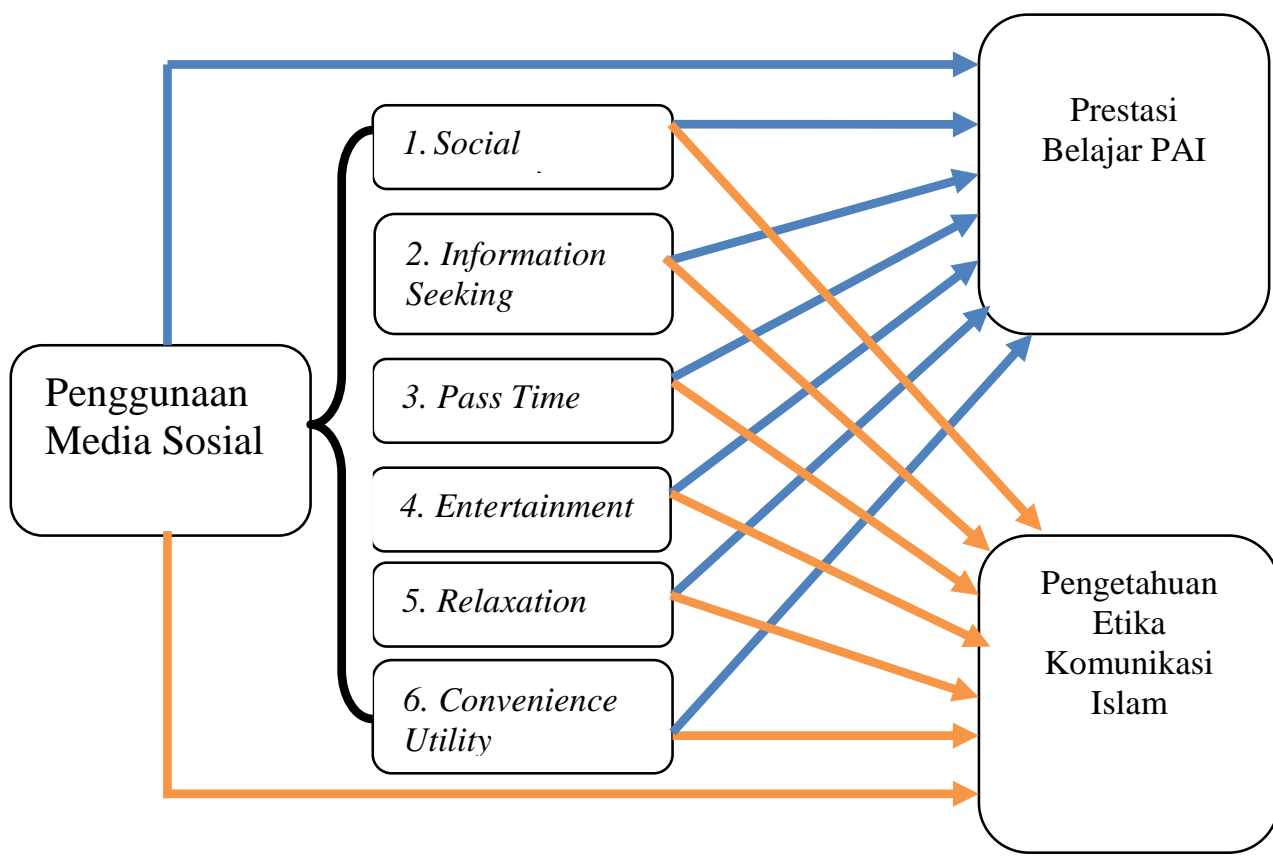

Gambar 1

Kerangka Berfikir Penelitian

${ }^{7}$ Harjani Hefni, Komunikasi islam (Jakarta: Prenada Media, 2015).

8 Ratna Istriyani dan Nur Huda Widiana, "Etika Komunikasi Islam Dalam Membendung Informasi Hoax di Ranah Publik Maya," Jurnal Ilmu Dakwah 36, no. 2 (2016): 288-315. 


\section{Metode Penelitian}

Penelitian ini menggunakan pendekatan studi korelasi., yaitu mencari hubungan dua atau lebih variabel, bagaimana arah hubungan tersebut serta sejauh mana hubungan tersebut dapat dijelaskan.

Populasi penelitian adalah siswa Kelas XI dan XII di SMA Muhammadiyah 1 Ngawi yang berjumlah 72 orang. Sampel merupakan bagian dari jumlah (wakil) dan karakteristik yang dimiliki oleh populasi yang diteliti'. Penelitian ini menggunakan teknik purposive sampling, siswa dan siswi kelas XI dan XII (IPA dan IPS) yang memiliki rentang usia antara 16 - 19 tahun yang berjumlah 51 siswa. Tahap perkembangan remaja akhir dimulai dari 16 hingga 19 tahun $^{10}$.

Pengumpulan data menggunakan : (1) Skala penggunaan media sosial yang disusun dari teori penggunaan dan gratifikasi berbentuk Skala Guttman . (2) Tes pengetahuan etika komunikasi Islam berdasarkan teori Hefni (2015). (3)Dokumentasi mengambil hasil prestasi belajar dari Nilai Raport PAI SMT Genap tahun akademik $2017 / 2018$.

Sebelum digunakan untuk mengambil data dalam penelitian, skala dan tes pengetahuan melalui serangkaian uji yaitu uji validasi ahli dan uji coba instrument. Uji validasi ahli telah dilakukan oleh validator ahli, dari psikolog pendidikan dan guru PAI SMA Muhammadiyah 1 Ngawi.

Tabel 1. Blue Print Skala Penggunaan Media Sosial

\begin{tabular}{|c|c|c|c|}
\hline No & Aspek & Favourable & Unfavourable \\
\hline 1 & Social interaction & 5 & 5 \\
\hline 2 & Information seeking & 5 & 5 \\
\hline 3 & Pass time & 5 & 5 \\
\hline 4 & Entertainment & 5 & 5 \\
\hline 5 & Relaxation & 5 & 5 \\
\hline 6 & Communicatory utility & 5 & 5 \\
\hline 7 & Convenience utility & 5 & 5 \\
\hline \multicolumn{2}{|c|}{} \\
\hline
\end{tabular}

Tabel 2. Penyebaran Skala Penggunaan Media Sosial

\begin{tabular}{|c|c|c|c|}
\hline No & Aspek & Favourable & Unfavourable \\
\hline 1 & Social interaction & $1,17,38,41,60$ & $2,18,31,46,65$ \\
\hline 2 & Information seeking & $4,23,32,42,61$ & $3,21,39,50,64$ \\
\hline 3 & Pass time & $10,19,37,47,62$ & $9,22,43,49,66$ \\
\hline 4 & Entertainment & $12,26,29,51,63$ & $13,28,40,52,67$ \\
\hline 5 & Relaxation & $11,20,30,45,56$ & $14,16,44,59,68$ \\
\hline 6 & Communicatory utility & $8,27,36,53,55$ & $7,25,34,58,69$ \\
\hline 7 & Convenience utility & $6,24,35,48,70$ & $5,15,33,57,54$ \\
\hline \multicolumn{2}{|c|}{35} & 35 \\
\hline \multicolumn{2}{|c|}{ Jumlah } & Total &
\end{tabular}

\footnotetext{
${ }^{9}$ Suharsimi Arikunto, Prosedur Penelitian: Suatu Pendekatan Praktik (Jakarta: Rineka Cipta, 2013).
}

${ }_{10}$ sarlito Wirawan Sarwono, Adolescent Psychology, Sar (Jakarta: Raja Grafindo Persada, 2006). 
Tabel 3. Blue Print Tes Pengetahuan Etika Komunikasi Islam

\begin{tabular}{|c|c|c|c|c|}
\hline \multirow{2}{*}{ No } & \multirow{2}{*}{ Aspek/ Prinsip } & \multicolumn{3}{|c|}{ Tingkat Kesulitan } \\
\hline & & Mudah & Sedang & Sulit \\
\hline 1 & Ikhlas & 2 & 2 & 2 \\
\hline 2 & Pahala dan Dosa & 2 & 2 & 2 \\
\hline 3 & Kejujuran & 2 & 2 & 2 \\
\hline 4 & Kebersihan & 2 & 2 & 2 \\
\hline 5 & Dua Telinga dan Satu Mulut & 2 & 2 & 2 \\
\hline 6 & Pengawasan & 2 & 2 & 2 \\
\hline 7 & Selektivitas dan Validitas & 2 & 2 & 2 \\
\hline 8 & Saling Memengaruhi & 2 & 2 & 2 \\
\hline 9 & Keseimbangan Berita & 2 & 2 & 2 \\
\hline 10 & Privacy & 2 & 2 & 2 \\
\hline & Jumlah & 20 & 20 & 20 \\
\hline & Total & \multicolumn{3}{|c|}{60} \\
\hline
\end{tabular}

Tabel 4. Penyebaran Item Tes Pengetahuan Etika Komunikasi Islam

\begin{tabular}{|c|c|c|c|c|}
\hline \multirow{2}{*}{ No } & \multirow{2}{*}{ Aspek/ Prinsip } & \multicolumn{3}{|c|}{ Tingkat Kesulitan } \\
\hline & & Mudah & Sedang & Sulit \\
\hline 1 & Ikhlas & 1,2 & 3,4 & 50,51 \\
\hline 2 & Pahala dan Dosa & 5,6 & 7,8 & 49,52 \\
\hline 3 & Kejujuran & 9,10 & 11,12 & 48,53 \\
\hline 4 & Kebersihan & 13,14 & 15,16 & 47,54 \\
\hline 5 & Dua Telinga dan Satu Mulut & 17,18 & 19,20 & 46,55 \\
\hline 6 & Pengawasan & 21,22 & 23,24 & 45,56 \\
\hline 7 & Selektivitas dan Validitas & 25,26 & 27,28 & 44,57 \\
\hline 8 & Saling Memengaruhi & 29,30 & 31,32 & 43,58 \\
\hline 9 & Keseimbangan Berita & 33,34 & 35,36 & 42,59 \\
\hline 10 & Privacy & 37.38 & 39,40 & 41,60 \\
\hline & Jumlah & 20 & 20 & 20 \\
\hline & Total & & 60 & \\
\hline
\end{tabular}

Uji coba instrumen yang diberikan kepada 72 siswa. Setelah itu dilakukan uji validasi dan uji reliabilitas menggunakan program aplikasi SPSS. Reliabilitas adalah sejauh mana hasil suatu alat ukur dapat memberikan hasil pengukuran yang relatif tidak berbeda setelah dilakukan pengukuran beberapa kali. ${ }^{11}$

Uji validitas item dapat dilakukan dengan membandingkan nilai corrected item total corellation dengan $\mathrm{r}$ tabel product moment level of significance 0.05 and 2 tailed. Suatu data dinyatakan valid apabila nilai koefisiennya positif dan lebih besar dari $\mathrm{r}$ tabel Product Moment level of significance 0.05 and 2 Tailed. Begitu sebaliknya, data dinyatakan tidak valid apabila nilai koefisiennya negative dan lebih kecil dari $\mathrm{r}$ tabel Product Moment level of significance 0.05 and 2 Tailed. ${ }^{12}$

${ }^{11}$ Sugiyono, Metode Penelitian Kuantitatif, Kualitatif dan RerD (Bandung: Alfabeta, 2008).

12 Dwi Priyatno, 5 Jam Olah Data dengan SPSS 17 (Yogyakarta: Andi Offset, 2009). 
Skor skala penggunaan media sosial dan tes pengetahuan etika komunikasi Islam di media sosial dikelompokkan menjadi 3 kategori. Dengan menggunakan kategorisasi Azwar yang bertujuan menempatkan individu ke dalam kelompok terpisah secara berjenjang menurut suatu kontinum berdasarkan atribut yang diukur (Azwar, 2012: 147). Rumus kategorisasi Azwar sebagai beikut: ${ }^{13}$

$$
\begin{array}{ll}
\text { Rendah: }(M-1 S D)<X \\
\text { Sedang } & :(M-1 S D) \leq X<(M+1 S D) \\
\text { Tinggi } & :(M+1 S D) \leq X
\end{array}
$$

Daya beda atau uji beda amerupakan kemampuan soal atau pertanyaan untuk membedakan siswa yang memiliki kemampuan tinggi dan rendah. ${ }^{14}$ Untuk menghitung hasil uji beda dari suatu soal, peneliti menggunakan bantuan aplikasi SPSS. Dan hasil uji beda tersebut dianalisa dengan melihat $\mathrm{r}$ hitung Pearson Correlation dari masing-masing item. Menurut Ebel (1979), kriteria tingkat uji beda tiap soal adalah: ${ }^{15}$

Tabel 5. Kriteria Uji Beda Item

\begin{tabular}{|c|c|c|}
\hline o & $\begin{array}{c}\text { Indeks } \\
\text { Angka }\end{array}$ & Evaluasi \\
\hline & $0.4-1.00$ & Soal baik \\
\hline & $0.3-0.39$ & $\begin{array}{c}\text { Soal diterima dan } \\
\text { diperbaiki }\end{array}$ \\
\hline & $0.2-0.29$ & Soal diperbaiki \\
\hline & $0.1-0.19$ & Soal ditolak \\
\hline
\end{tabular}

Pertanyaan atau soal yang baik adalah soal yang berisi pertanyaan yang tidak terlalu mudah dan tidak terlalu sulit atau sedang. ${ }^{16}$ Hasil uji kesukaran tersebut dianalisa dengan melihat Mean atau rata-rata dari masing-masing item. Dengan kriteria tingkat uji kesukaran tiap soal adalah:

Tabel 6. Kriteria Uji Kesukaran Item ${ }^{17}$

\begin{tabular}{|c|c|c|}
\hline No & Indeks Angka & Evaluasi \\
\hline 1 & $0.00-0.20$ & Sukar \\
\hline 2 & $0.21-0.70$ & Sedang \\
\hline 3 & $0.71-1.00$ & Mudah \\
\hline
\end{tabular}

Proses mengorganisasikan dan mengurutkan data ke dalam pola, kategori, dan satuan uraian dasar sehingga dapat ditemukan tema dan dapat dirumuskan hipotesis kerja disebut sebagai analisis data. ${ }^{18}$

${ }^{13}$ Saifuddin Azwar, Tes Prestasi Fungsi Pengembangan Pengukuran Prestasi Belajar, 2 ed. (Yogyakarta: Pustaka Pelajar, 2013).

14 Daryanto, Dasar-Dasar Evaluasi Pendidikan (Jakarta: Bumi Aksara, 2005).

15 Azwar, Tes Prestasi Fungsi Pengembangan Pengukuran Prestasi Belajar.

${ }^{16}$ Daryanto, Evaluasi Pendidikan (Jakarta: Rineka Cipta, 2001).

${ }^{17}$ Arikunto, Prosedur Penelitian: Suatu Pendekatan Praktik.

${ }^{18}$ Lexy J Moleong, Metode Penelitian Kualitatif (Bandung: Remaja Rosdakarya, 2012). 
Penelitian ini menggunakan analisis statistik parametrik karena jumlah sampel penelitian lebih dari 30 orang. Analisis parametrik yang digunakan berupa uji Bivariate Correlation Product Moment Pearson dengan menggunakan aplikasi SPSS. Penelitian ini menggunakan Product Moment Pearson karena mempunyai distribusi data normal, dan berupa data interval.

\section{Hasil dan Pembahasan}

\section{Uji Instrumen}

Hasil uji validitas dan reliabilitas skala penggunaan media sosial dijabarkan dalam tabel berikut ini

Tabel 7. Hasil Uji Validitas Skala Penggunaan Media Sosial

\begin{tabular}{|c|c|c|c|c|c|}
\hline No & $\begin{array}{c}\text { No } \\
\text { Item }\end{array}$ & $\begin{array}{c}\text { Korelasi Item } \\
\text { Total }\end{array}$ & No & No Item & $\begin{array}{c}\text { Korelasi Item } \\
\text { Total }\end{array}$ \\
\hline 1 & I1 & .338 & 15 & I30 & .501 \\
\hline 2 & I10 & .684 & 16 & I42 & .501 \\
\hline 3 & I11 & .544 & 17 & I44 & .479 \\
\hline 4 & I12 & .665 & 18 & I48 & .719 \\
\hline 5 & I14 & .534 & 19 & I50 & .315 \\
\hline 6 & I16 & .477 & 20 & I51 & .722 \\
\hline 7 & I18 & .433 & 21 & I56 & .450 \\
\hline 8 & I19 & .589 & 22 & I61 & .305 \\
\hline 9 & I20 & .527 & 23 & I62 & .427 \\
\hline 10 & I21 & .307 & 24 & I63 & .702 \\
\hline 11 & I24 & .423 & 25 & I65 & .378 \\
\hline 12 & I26 & .413 & 26 & I66 & .650 \\
\hline 13 & I28 & .332 & 27 & I70 & .545 \\
\hline 14 & I29 & .620 & & & \\
\hline
\end{tabular}

Berdasarkan hasil uji validasi terdapat 43 item yang gugur dari 70 item. Dan item yang digunakan pada skala penggunaan media sosial berjumlah 27 item.. Penyebaran butir item skala penggunaan media sosial setelah diuji reliabilitas dan validitas dapat dilihat pada tabel berikut:

Tabel 8. Penyebaran Item Skala Penggunaan Media Sosial

\begin{tabular}{|c|c|c|c|}
\hline No & Aspek & Favourable & Unfavourable \\
\hline 1 & Social interaction & 1 & 18,56 \\
\hline 2 & Information seeking & 42,61 & 21,50 \\
\hline 3 & Pass time & $10,19,62$ & 66 \\
\hline 4 & Entertainment & $12,26,29,51,63$ & 28 \\
\hline 5 & Relaxation & $11,20,30,56$ & $14,16,44$ \\
\hline 6 & Convenience utility & $24,48,70$ & - \\
\hline \multicolumn{3}{|c|}{27} \\
\hline & Jumlah & 18 & 9 \\
\hline
\end{tabular}


Tabel 9. Hasil Uji Validitas Tes Pengetahuan Etika Komunikasi Islam

\begin{tabular}{|c|c|c|c|c|c|}
\hline No & No. Item & Hasil & No & No. Item & Hasil \\
\hline 1 & T9 & 0.380 & 16 & T36 & 0.429 \\
\hline 2 & T18 & 0.622 & 17 & T37 & 0.414 \\
\hline 3 & T19 & 0.430 & 18 & T39 & 0.478 \\
\hline 4 & T20 & 0.415 & 19 & T40 & 0.636 \\
\hline 5 & T21 & 0.603 & 20 & T41 & 0.311 \\
\hline 6 & T22 & 0.545 & 21 & T45 & 0.521 \\
\hline 7 & T23 & 0.753 & 22 & T46 & 0.616 \\
\hline 8 & T24 & 0.806 & 23 & T47 & 0.703 \\
\hline 9 & T25 & 0.688 & 24 & T49 & 0.400 \\
\hline 10 & T26 & 0.841 & 25 & T51 & 0.396 \\
\hline 11 & T27 & 0.748 & 26 & T52 & 0.753 \\
\hline 12 & T31 & 0.432 & 27 & T53 & 0.336 \\
\hline 13 & T32 & 0.616 & 28 & T56 & 0.404 \\
\hline 14 & T33 & 0.631 & 29 & T57 & 0.504 \\
\hline 15 & T35 & 0.646 & 30 & T60 & 0.478 \\
\hline
\end{tabular}

Berdasarkan hasil uji coba terdapat 30 item yang gugur, maka dari total 60 item, yang akan digunakan dalam tes pengetahuan etika komunikasi Islam sebanyak 30 item.. Penyebaran item tes pengetahuan setelah diuji validitas adalah sebagai berikut:

Tabel 10. Penyebaran Item Tes Pengetahuan Etika Komunikasi Islam

\begin{tabular}{|c|c|c|c|}
\hline \multirow{2}{*}{ No } & \multirow{2}{*}{ Aspek } & \multicolumn{2}{|c|}{ Tingkat Kesulitan } \\
\cline { 3 - 4 } & & Mudah & Sedang \\
\hline 1 & Ikhlas & 49,52 & 51 \\
\hline 2 & Pahala dan dosa & 9, & 53 \\
\hline 3 & Kejujuran & 47 & 19 \\
\hline 4 & Kebersihan & $18,20,46$ & \\
\hline 5 & Dua telinga dan satu mulut & $21,22,23,24,45,56$ & 31 \\
\hline 6 & Pengawasan & $25,26,27,57$ & 36 \\
\hline 7 & Selektivitas dan validitas & 33,35 & $37,41,60$ \\
\hline 8 & Saling memengaruhi & 39,40, & 8 \\
\hline 9 & Keseimbangan berita & 22 & \\
\hline 10 & Privacy & & 30 \\
\hline & Jumlah & & \\
\hline \multicolumn{3}{r}{}
\end{tabular}

Hasil uji validitas dan reliabilitas tes pengetahuan etika komunikasi Islam di uraikan dalam tabel dibawah ini 
Tabel 11. Skor dan Kategori Skala Penggunaan Media Sosial, Tes Etika engetahuan Komunikasi Islam dan Prestasi Belajar PAI

\begin{tabular}{|c|c|c|c|c|c|c|c|c|}
\hline \multirow{2}{*}{ No } & \multirow{2}{*}{$\begin{array}{l}\text { Nama/ } \\
\text { Inisial }\end{array}$} & \multirow{2}{*}{$\mathrm{L} / \mathrm{P}$} & \multicolumn{2}{|c|}{ Skala Media } & \multicolumn{2}{|c|}{ Tes Pengetahuan } & \multicolumn{2}{|c|}{ Nilai PAI } \\
\hline & & & Skor & Kategori & Skor & Kategori & Skor & Kategori \\
\hline 1 & AR & $\mathrm{L}$ & 17 & Sedang & 26 & Sedang & 80 & Sedang \\
\hline 2 & $\overline{\mathrm{DE}}$ & $\mathrm{L}$ & 21 & Sedang & 24 & Sedang & 80 & Sedang \\
\hline 3 & DD & $\mathrm{L}$ & 24 & Sedang & 25 & Sedang & 85 & Sedang \\
\hline 4 & DS & $\mathrm{P}$ & 22 & Sedang & 27 & Sedang & 85 & Sedang \\
\hline 5 & FB & $\mathrm{L}$ & 20 & Sedang & 25 & Sedang & 85 & Sedang \\
\hline 6 & GB & $\mathrm{P}$ & 24 & Sedang & 28 & Sedang & 85 & Sedang \\
\hline 7 & IS & $\mathrm{P}$ & 24 & Sedang & 25 & Sedang & 85 & Sedang \\
\hline 8 & MI & $\mathrm{P}$ & 22 & Sedang & 24 & Sedang & 80 & Sedang \\
\hline 9 & $\mathrm{MK}$ & $\mathrm{L}$ & 25 & Sedang & 24 & Sedang & 80 & Sedang \\
\hline 10 & OD & $\mathrm{P}$ & 24 & Sedang & 27 & Sedang & 85 & Sedang \\
\hline 11 & RK & $\mathrm{P}$ & 21 & Sedang & 27 & Sedang & 85 & Sedang \\
\hline 12 & SI & $\mathrm{P}$ & 17 & Sedang & 21 & Sedang & 80 & Sedang \\
\hline 13 & TO & $\mathrm{L}$ & 27 & Tinggi & 20 & Sedang & 85 & Sedang \\
\hline 14 & $\mathrm{YS}$ & $\mathrm{P}$ & 22 & Sedang & 28 & Sedang & 85 & Sedang \\
\hline 15 & $\mathrm{KS}$ & $\mathrm{L}$ & 23 & Sedang & 21 & Sedang & 80 & Sedang \\
\hline 16 & DW & $\mathrm{P}$ & 24 & Sedang & 24 & Sedang & 75 & Rendah \\
\hline 17 & ED & $\mathrm{L}$ & 25 & Sedang & 26 & Sedang & 75 & Rendah \\
\hline 18 & $\mathrm{EH}$ & $\mathrm{P}$ & 25 & Sedang & 26 & Sedang & 75 & Rendah \\
\hline 19 & IN & $\mathrm{P}$ & 26 & Sedang & 25 & Sedang & 70 & Rendah \\
\hline 20 & $\mathrm{LP}$ & $\mathrm{P}$ & 23 & Sedang & 27 & Sedang & 85 & Sedang \\
\hline 21 & NI & $\mathrm{L}$ & 26 & Sedang & 24 & Sedang & 75 & Rendah \\
\hline 22 & $\mathrm{SP}$ & $\mathrm{L}$ & 25 & Sedang & 23 & Sedang & 85 & Sedang \\
\hline 23 & SGI & $\mathrm{L}$ & 7 & Rendah & 20 & Sedang & 75 & Rendah \\
\hline 24 & SGA & $\mathrm{L}$ & 13 & Rendah & 23 & Sedang & 85 & Sedang \\
\hline 25 & ARO & $\mathrm{P}$ & 21 & Sedang & 28 & Sedang & 85 & Sedang \\
\hline 26 & BD & $\mathrm{P}$ & 9 & Rendah & 20 & Sedang & 90 & Tinggi \\
\hline 27 & DSY & $\mathrm{L}$ & 5 & Rendah & 27 & Sedang & 83 & Sedang \\
\hline 28 & $\mathrm{FS}$ & $\mathrm{L}$ & 25 & Sedang & 22 & Sedang & 80 & Sedang \\
\hline 29 & HS & $\mathrm{P}$ & 22 & Sedang & 26 & Sedang & 85 & Sedang \\
\hline 30 & $\mathrm{JP}$ & $\mathrm{P}$ & 23 & Sedang & 24 & Sedang & 85 & Sedang \\
\hline 31 & $\mathrm{KN}$ & $\mathrm{L}$ & 23 & Sedang & 25 & Sedang & 83 & Sedang \\
\hline
\end{tabular}

Tabel 12. Skor Aspek-Aspek Penggunaan Media Sosial

\begin{tabular}{|c|c|c|c|c|c|c|c|c|c|}
\hline \multirow{2}{*}{ No } & \multirow{2}{*}{ Nama } & \multirow{2}{*}{$\mathrm{L} / \mathrm{P}$} & \multicolumn{6}{|c|}{ Aspek } & \multirow{2}{*}{ Total } \\
\cline { 4 - 10 } & & & Sos & Info & Pass & Entr & Relax & Conv & \\
\hline 1 & AR & $\mathrm{L}$ & 2 & 2 & 2 & 3 & 5 & 3 & 17 \\
\hline 2 & $\mathrm{DE}$ & $\mathrm{L}$ & 3 & 2 & 3 & 5 & 5 & 3 & 21 \\
\hline 3 & $\mathrm{DD}$ & $\mathrm{L}$ & 3 & 4 & 4 & 5 & 5 & 3 & 24 \\
\hline 4 & $\mathrm{DS}$ & $\mathrm{P}$ & 1 & 3 & 4 & 5 & 6 & 3 & 22 \\
\hline 5 & $\mathrm{FB}$ & $\mathrm{L}$ & 3 & 4 & 3 & 4 & 4 & 2 & 20 \\
\hline 6 & $\mathrm{~GB}$ & $\mathrm{P}$ & 2 & 3 & 4 & 5 & 7 & 3 & 24 \\
\hline 7 & $\mathrm{IS}$ & $\mathrm{P}$ & 3 & 3 & 4 & 5 & 6 & 3 & 24 \\
\hline 8 & $\mathrm{MI}$ & $\mathrm{P}$ & 3 & 3 & 4 & 4 & 6 & 2 & 22 \\
\hline
\end{tabular}




\begin{tabular}{|c|c|c|c|c|c|c|c|c|c|}
\hline 9 & MK & $\mathrm{L}$ & 2 & 3 & 4 & 6 & 7 & 3 & 25 \\
\hline 10 & OD & $\mathrm{P}$ & 2 & 4 & 4 & 6 & 5 & 3 & 24 \\
\hline 11 & RK & $\mathrm{P}$ & 1 & 2 & 4 & 4 & 7 & 3 & 21 \\
\hline 12 & SI & $\mathrm{P}$ & 1 & 2 & 4 & 5 & 3 & 2 & 17 \\
\hline 13 & TO & $\mathrm{L}$ & 3 & 4 & 4 & 6 & 7 & 3 & 27 \\
\hline 14 & YS & $\mathrm{P}$ & 3 & 3 & 3 & 5 & 6 & 2 & 22 \\
\hline 15 & KS & $\mathrm{L}$ & 2 & 2 & 4 & 6 & 6 & 3 & 23 \\
\hline 16 & DW & $\mathrm{P}$ & 3 & 4 & 4 & 6 & 6 & 1 & 24 \\
\hline 17 & ED & $\mathrm{L}$ & 3 & 4 & 4 & 6 & 5 & 3 & 25 \\
\hline 18 & $\mathrm{EH}$ & $\mathrm{P}$ & 3 & 2 & 4 & 6 & 7 & 3 & 25 \\
\hline 19 & IN & $\mathrm{P}$ & 3 & 4 & 4 & 6 & 6 & 3 & 26 \\
\hline 20 & LP & $\mathrm{P}$ & 2 & 4 & 4 & 5 & 5 & 3 & 23 \\
\hline 21 & $\mathrm{NI}$ & $\mathrm{L}$ & 3 & 4 & 4 & 5 & 7 & 3 & 26 \\
\hline 22 & SP & $\mathrm{L}$ & 3 & 2 & 4 & 6 & 7 & 3 & 25 \\
\hline 23 & SGI & $\mathrm{L}$ & 2 & 0 & 1 & 1 & 3 & 0 & 7 \\
\hline 24 & SGA & $\mathrm{L}$ & 1 & 2 & 2 & 3 & 2 & 3 & 13 \\
\hline 25 & ARO & $\mathrm{P}$ & 3 & 3 & 3 & 3 & 6 & 3 & 21 \\
\hline 26 & BD & $\mathrm{P}$ & 1 & 1 & 2 & 1 & 2 & 2 & 9 \\
\hline 27 & DSY & $\mathrm{L}$ & 1 & 2 & 0 & 1 & 0 & 1 & 5 \\
\hline 28 & FS & $\mathrm{L}$ & 3 & 3 & 4 & 6 & 6 & 3 & 25 \\
\hline 29 & HS & $\mathrm{P}$ & 3 & 3 & 3 & 6 & 5 & 2 & 22 \\
\hline 30 & JP & $\mathrm{P}$ & 2 & 3 & 4 & 5 & 6 & 3 & 23 \\
\hline 31 & $\mathrm{KN}$ & $\mathrm{L}$ & 1 & 3 & 4 & 5 & 7 & 3 & 23 \\
\hline 32 & $\mathrm{NH}$ & $\mathrm{P}$ & 1 & 1 & 4 & 2 & 5 & 3 & 16 \\
\hline 33 & RA & $\mathrm{L}$ & 2 & 1 & 4 & 1 & 1 & 1 & 10 \\
\hline 34 & SA & $\mathrm{P}$ & 1 & 3 & 3 & 5 & 6 & 3 & 21 \\
\hline 35 & SP & $\mathrm{P}$ & 1 & 3 & 4 & 5 & 6 & 3 & 22 \\
\hline 36 & $\mathrm{SN}$ & $\mathrm{P}$ & 1 & 3 & 2 & 4 & 3 & 1 & 14 \\
\hline 37 & SW & $\mathrm{P}$ & 1 & 1 & 3 & 5 & 5 & 2 & 17 \\
\hline 38 & WP & $\mathrm{P}$ & 2 & 2 & 4 & 4 & 2 & 2 & 16 \\
\hline 39 & AA & $\mathrm{L}$ & 1 & 0 & 1 & 1 & 0 & 0 & 3 \\
\hline 40 & AM & $\mathrm{L}$ & 3 & 3 & 4 & 6 & 7 & 3 & 26 \\
\hline 41 & DIW & $\mathrm{P}$ & 3 & 4 & 4 & 5 & 6 & 3 & 25 \\
\hline 42 & $\mathrm{DA}$ & $\mathrm{P}$ & 3 & 3 & 1 & 4 & 3 & 3 & 17 \\
\hline 43 & DNA & $\mathrm{P}$ & 2 & 3 & 4 & 6 & 6 & 3 & 24 \\
\hline 44 & JK & $\mathrm{L}$ & 3 & 3 & 4 & 6 & 5 & 2 & 23 \\
\hline 45 & LR & $\mathrm{P}$ & 0 & 2 & 0 & 1 & 1 & 1 & 5 \\
\hline 46 & NPR & $\mathrm{P}$ & 2 & 3 & 4 & 6 & 6 & 3 & 24 \\
\hline 47 & SM & $\mathrm{P}$ & 1 & 3 & 4 & 6 & 7 & 3 & 24 \\
\hline 48 & ST & $\mathrm{L}$ & 1 & 2 & 3 & 6 & 5 & 3 & 20 \\
\hline 49 & TD & $\mathrm{L}$ & 2 & 4 & 3 & 3 & 4 & 3 & 19 \\
\hline 50 & $\mathrm{YF}$ & $\mathrm{L}$ & 3 & 3 & 3 & 3 & 5 & 3 & 20 \\
\hline 51 & LM & $\mathrm{P}$ & 3 & 3 & 4 & 6 & 6 & 3 & 25 \\
\hline
\end{tabular}




\section{Uji Korelasi}

1. Uji Korelasi Penggunaan Media Sosial dengan Pengetahuan Etika Komunikasi Islam

a. Uji korelasi antara skor total skala penggunaan media sosial dengan skor total tes pengetahuan etika komunikasi Islam di media sosial. Taraf signifikansi 0,061, tidak ada hubungan antara penggunaan media sosial dengan pengetahuan etika komunikasi Islam di media sosial pada siswa.

b. Uji korelasi antara skor aspek skala penggunaan media sosial dengan skor tes pengetahuan etika komunikasi Islam di media sosial

1) Korelasi antara aspek social interaction dengan etika komunikasi Islam menunjukkan taraf signifikansi 0,030, ada hubungan antara penggunaan media sosial aspek social interaction dengan pengetahuan etika komunikasi Islam di media sosial. Semakin tinggi pengetahuan etika komunikasi islam semakin tinggi penggunaan media sosial untuk interaksi sosial.

2) Korelasi antara aspek information seeking dengan etika komunikasi Islam menunjukkan nilai sebesar 0.071, tidak ada hubungan antara penggunaan media sosial aspek information seeking dengan pengetahuan etika komunikasi Islam.

3) Korelasi antara aspek pass time dengan pengetahuan etika komunikasi Islam menunjukkan nilai sebesar 0.726 yaitu lebih besar dari 0.05, maka Ho diteriam. Jadi tidak ada hubungan antara penggunaan media sosial aspek pass time dengan pengetahuan etika komunikasi Islam.

4) Korelasi antara aspek entertainment dengan pengetahuan etika komunikasi Islam menunjukkan nilai sebesar 0.287 tidak ada hubungan antara penggunaan media sosial aspek entertainment dengan pengetahuan etika komunikasi Islam.

5) Korelasi antara aspek relaxation dengan pengetahuan etika komunikasi Islam menunjukkan nilai sebesar 0.049 ada hubungan antara penggunaan media sosial aspek relaxation dengan pengetahuan etika komunikasi Islam. Semakin tinggi pengetahuan etika komunikasi islam semakin tinggi penggunaan media sosial untuk relaxation.

6) Korelasi antara aspek convenience utility dengan pengetahuan etika komunikasi Islam di media sosial menunjukkan nilai sebesar 0.068 yaitu lebih besar dari 0.05, tidak ada hubungan antara penggunaan media sosial aspek convenience utility dengan pengetahuan etika komunikasi Islam .

2. Uji Korelasi Penggunaan Media Sosial dengan Prestasi Belajar PAI

a. Uji korelasi antara skor total skala penggunaan media sosial dengan prestasi belajar PAI di rapor semester genap 2017/2018. Korelasi antara penggunaan media sosial dengan prestasi belajar PAI menunjukkan nilai sebesar 0.472, Jadi dapat disimpulkan tidak ada hubungan antara penggunaan media sosial dengan prestasi belajar PAI pada siswa.

b. Uji korelasi antara setiap aspek skala penggunaan media sosial dengan prestasi belajar PAI 
1) Korelasi antara aspek social interaction dengan prestasi belajar PAI menunjukkan nilai sebesar 0.240 ,. Jadi tidak ada hubungan antara penggunaan media sosial aspek social interation dengan prestasi belajar PAI.

2) Korelasi antara aspek information seeking dengan prestasi belajar PAI menunjukkan nilai sebesar 0.426 tidak ada hubungan antara penggunaan media sosial aspek information seeking dengan prestasi belajar PAI.

3) Korelasi antara aspek pass time dengan prestasi belajar PAI menunjukkan nilai koefisien -0,152, tidak ada hubungan antara penggunaan media sosial aspek pass time dengan prestasi belajar PAI.

4) Korelasi antara aspek entertainment dengan prestasi belajar PAI menunjukkan nilai sebesar 0.215. tidak ada hubungan antara penggunaan media sosial aspek entertainment dengan prestasi belajar PAI.

5) Korelasi antara aspek relaxation dengan prestasi belajar PAI menunjukkan nilai 0.319 tidak ada hubungan antara penggunaan media sosial aspek relaxation dengan prestasi belajar PAI.

6) Korelasi antara aspek convenience utility dengan prestasi belajar PAI menunjukkan nilai sebesar 0.219 , tidak ada hubungan antara penggunaan media sosial aspek convenience utility dengan prestasi belajar PAI.

\section{Pembahasan}

Menurut Best, Manktelow dan Taylor (2014), media sosial bersifat netral atau bebas nilai dan perannya hanya sebagai fasilitator bagi interaksi manusia. ${ }^{19}$. hasil yang diperoleh seseorang dalam menggunakan media sosial tergantung kemampuannya sendiri dalam mengelola penggunaan media sosial untuk kebaikan dirinya.

Hasil penelitian menunjukkan tidak ada hubungan signifikan antara penggunaan media sosial dan pengetahuan etika islam. Akan tetapi secara khusus, terdapat hubungan signifikan antara pengetahuan etika komunikasi islam dengan aspek interaksi sosial dan relaksasi.

Hal ini mengindikasikan bahwa subyek penelitian merasa memiliki pedoman yang benar untuk aktif dalam media sosial tanpa memiliki pengetahuan terhadap pedoman agama, subyek penelitian cenderung untuk menghindari menggunakan media sosial.

Studi yang dilaksanakan Saputra (2016) memaparkan adanya perbedaan antara remaja yang memiliki latar belakang pndidikan agama dan tidak memiliki latar belakang pendidikan agama. Remaja yang memiliki latar belakang pendidikan agama memiliki taraf penyimpangan yang lebih rendah dalm penggunaan media sosial daripada remaja yang tidak memiliki latar belakang pendidikan agama ${ }^{20}$. Pengetahuan ini juga

19 Paul Best, Roger Manktelow, dan Brian Taylor, "Online Communication, social Media and AdolescenceWellbeing:A Systematic Narrative Review," Children and Youth Service Rview 41 (Juni 2014): 2736.

${ }^{20}$ Edy Saputra, "Dampak Sosial Media TerhadapKeberagamaan Remaja dan Solusinya Melalui Pendidikan Agama islam,” Sosio e Kons 8, no. 2 (2 Agustus 2016): 160-68. 
membuatnya nyaman menggunakan media sosial sehingga mereka bisa menggunakannya sebagai sarana untuk relaksasi dari kepenatan yang dihadapi.

Hal ini sesuai dengan pendapat Hefni bahwa prinsip kebersihan dalam berkomunikasi akan menimbulkan kenyamanan psikologis karena pesan yang disampaikan merupakan pesan yang baik ${ }^{21}$

Etika Komunikasi Islam bersumber pada inti ajaran Islam. seperti yang diungkapkan Suryana bahwa esensi Ajaran islam terletak pada penghargaan terhadap kemanusiaan secara universal dan menganjurkan hubungan sosial dalam kebaikan tanpa membedakan agama dan bangsa ${ }^{22}$.

Tidak adanya hubungan antara penggunaan media sosial dengan prestasi belajar PAI mengindikasikan penggunaan media sosial subyek penelitian tidak dikaitkan atau digunakan sebagai media pembelajaran dalam kegiatan belajar mata pelajaran PAI.

Beberapa penelitian lain juga menunjukkan hasil yang sama, yaitu penelitian Ester, tuchunan dan Rumayar (2018) menyebutkan tidak adanya hubungan antara penggunaan media sosial dengan prestasi belajar Siswa kelas XI SMA Manado ${ }^{23}$.

Penelitian Tezer, Taspolat dan sami kaya (2017) menggambarkan hubungan tidak signifikan antara penggunaan sosial media dan prestasi akademik. Akan tetapi mahasiswa yang memiliki akun media sosial terlihat memiliki prestasi akademik yanbg lebih tinggi daripada mahasiswa yang tidak memiliki akun media sosial. ${ }^{24}$

\section{Catatan Akhir}

Hasil penelitian menunjukkan tidak ada hubungan penggunaan media sosial terhadap etika komunikasi di media sosial dalam Islam dan prestasi belajar PAI. Tetapi penggunaan media sosial pada aspek social interaction dan relaxation memiliki hubungan dengan pengetahuan etika komunikasi Islam.

Hasil penelitian ini menunjukkan tidak ada hubungan penggunaan media sosial dengan prestasi belajar PAI.

Berdasarkan hasil penelitian, peneliti memberikan saran pada berbagai pihak diantaranya adalah; pertama siswa dapat menambah pengetahuan etika komunikasi Islam dan menerapkannya dalam penggunaan media sosial terutama dalam interaksi sosial.

Kedua, Bagi Lembaga Pendidikan dapat memaksimalkan dalam melakukan pendidikan etika komunikasi Islam sehingga dapat digunakan siswa sebagai pedoman dalam menggunakan media sosial terutama dalam aspek social interaction dan relaxation.

Ketiga. Diharapkan peneliti selanjutnya dapat memperbaiki validitas internal skala penggunaan media sosial dan tes pengetahuan etika komunikasi Islam. Meneliti lebih

\footnotetext{
${ }^{21}$ Hefni, Komunikasi islam.

22 Toto Suryana, "Konsep dan Aktualisasi Kerukunan Antar Umat Beragama," Jurnal Pendidikan Islam Ta'lim 9, no. 2 (2011): 127-36.

23 Bella Vista Esther, A.A.T Tuchunan, dan A.A Rumayar, "Hubungan Penggunaan Media Sosial dengan Prestasi Akademik Belajar Kelas XI di SMA Negeri 1 Manado," KESMAS 7, no. 4 (J uli 2018).

24 Murat Tezer, Ata Taspolat, dan Omer Sami Kaya, "The Impact of using Social Mediaon academic Achievement and Attitudes of Prospective Teachers," IJCRSEE 5, no. 2 (2017): 75-81, https://doi.org/10.5937/IJCSREE1702075T.
} 
lanjut tentang hubungan social interaction dan relaxation dengan etika pengetahuan komunikasi Islam.

\section{Daftar Rujukan}

Arikunto, Suharsimi. Prosedur Penelitian: Suatu Pendekatan Praktik. Jakarta: Rineka Cipta, 2013.

Arsyad, Azhar. Media Pembelajaran. Jakarta: PT Raja Grafindo Persada, 2011.

Azwar, Saifuddin. Tes Prestasi Fungsi Pengembangan Pengukuran Prestasi Belajar. 2 ed. Yogyakarta: Pustaka Pelajar, 2013.

Best, Paul, Roger Manktelow, dan Brian Taylor. "Online Communication, social Media and AdolescenceWellbeing:A Systematic Narrative Review." Children and Youth Service Rview 41 (Juni 2014): 27-36.

Daryanto. Dasar-Dasar Evaluasi Pendidikan. Jakarta: Bumi Aksara, 2005.

—. Evaluasi Pendidikan. Jakarta: Rineka Cipta, 2001.

Esther, Bella Vista, A.A.T Tuchunan, dan A.A Rumayar. "Hubungan Penggunaan Media Sosial dengan Prestasi Akademik Belajar Kelas XI di SMA Negeri 1 Manado." KESMAS 7, no. 4 (J uli 2018).

Hefni, Harjani. Komunikasi islam. Jakarta: Prenada Media, 2015.

Istriyani, Ratna, dan Nur Huda Widiana. "Etika Komunikasi Islam Dalam Membendung Informasi Hoax di Ranah Publik Maya." Jurnal Ilmu Dakwah 36, no. 2 (2016): 288-315.

KOMINFO. "Pengguna Internet i Indonesia 63 Juta orang," 7 November 2011. kominfo.go.od.

- "Riset KOMINFO dan UNICEF Mengenai Perilaku Anak dan Remaja Menggunakan Internet," 18 Februari 2014. kominfo.go.id.

Moleong, Lexy J. Metode Penelitian Kualitatif. Bandung: Remaja Rosdakarya, 2012.

Priyatno, Dwi. 5 Jam Olah Data dengan SPSS 17. Yogyakarta: Andi Offset, 2009.

Putri, Wilga Sersio Ratsja, R. Nunung Nurwati, dan Budiarti S Meilanny. "Pengaruh Media Sosial Terhadap Perilaku Remaja." Prosiding KS ;Riset dan PKM 3, no. 1 (2017): 47-51.

Saputra, Edy. "Dampak Sosial Media TerhadapKeberagamaan Remaja dan Solusinya Melalui Pendidikan Agama islam." Sosio e Kons 8, no. 2 (2 Agustus 2016): 160-68.

Sarwono, sarlito Wirawan. Adolescent Psychology. Sar. Jakarta: Raja Grafindo Persada, 2006. Sugiyono. Metode Penelitian Kuantitatif, Kualitatif dan R\&D. Bandung: Alfabeta, 2008.

Suryana, Toto. "Konsep dan Aktualisasi Kerukunan Antar Umat Beragama." Jurnal Pendidikan Islam Ta'lim 9, no. 2 (2011): 127-36.

Tezer, Murat, Ata Taspolat, dan Omer Sami Kaya. "The Impact of using Social Mediaon academic Achievement and Attitudes of Prospective Teachers." IJCRSEE 5, no. 2 (2017): 75-81. https://doi.org/10.5937/IJCSREE1702075T.

Whiting, Anita, dan David William. "Why people use social media: A uses and gratifications approach." QMRIJ 16, no. 4 (Juni 2013). https://doi.org/10.1108/QMR-06-2013-0041. 